\title{
11 \\ Paul Hasluck with Dr Evatt at the United Nations
}

\author{
Geoffrey Bolton
}

\begin{abstract}
Assessments of Dr H.V. Evatt's performance in the formative years of the United Nations from 1945 to 1947 have drawn on the critical comments voiced by Paul Hasluck in several publications. ${ }^{1}$ Hasluck wrote with the authority of one who served in the Department of External Affairs with Evatt for more than five years, and had a justified reputation as a scrupulous historian whose judgments tried to avoid political bias. This essay, drawing on unpublished material in the Hasluck family archives, will show that for much of their association at External Affairs, Hasluck's outlook on foreign policy was closer to Evatt's than his subsequent writings might suggest. ${ }^{2}$
\end{abstract}

A successful Western Australian journalist, poet, drama critic and historian, Paul Hasluck was recruited to the Department of External Affairs in February 1941 on a temporary basis. He found his early months in Canberra undemanding and disappointing, but allowed himself to hope for improvement in October 1941 when the Curtin Labor Government took office and Dr Evatt was appointed minister for External Affairs. A former judge of the High Court, Evatt was known to be an intellectual with broad cultural sympathies. Disillusion came soon. A fortnight after Evatt's appointment Hasluck wrote in his diary: 'He has not come near us yet, has upset the Department on several matters and generally shows a disposition to try and find something to reform or "squash" rather than to understand. ${ }^{3}$

Hasluck thought seriously of returning to Perth, but all changed in December when Japan entered the war and he saw it as his duty to stay at his post. During 1942 he became officer-in-charge of a new section of the Department of External Affairs on post-war policy and came to be seen as the department's authority in the field. He was good at his job, though he often fretted about bureaucratic

\footnotetext{
1 P. Hasluck, Workshop of Security (Melbourne: F.W. Cheshire, 1948); 'Australia and the formation of the United Nations', Royal Australian Historical Society, Journal and Proceedings, xl, no. iii (1954), 133-78; Diplomatic Witness: Australian Foreign Affairs 1941-1947 (Carlton: Melbourne University Press, 1977).

2 Some of the material covered in this chapter is also addressed in G. Bolton, Paul Hasluck: A Life (Crawley, WA: UWA Publishing, 2014).

3 P. Hasluck, Diary 1941-42, 20 October 1941, Hasluck MSS, Claremont.
} 
in-fighting. ${ }^{4}$ When Evatt went to the Food and Agriculture Conference at Hot Springs in Virginia in April 1943, instead of taking Hasluck with him, he borrowed Hasluck's friend, Dr H.C. Coombs, from the Department of Labour and National Service. At the conference Coombs distinguished himself by his advocacy of full employment as a post-war objective. To represent External Affairs, Evatt took with him his recently appointed private secretary, Dr John Burton.

With Hasluck, like himself an appointee from outside the departmental cadre, Burton was at first on friendly terms to the extent of suggesting that during his absence abroad Hasluck might escort his wife Cecily to the cinema. They shared little jokes about Evatt: 'I find the Minister rarely has much idea of the line he wants to follow,' Burton wrote to Hasluck, 'and he will accept a draft quite easily. I have not had so many ideas put over for a long time! The boss has behaved quite well and everyone is commenting that he is much less difficult this time than last. ${ }^{5}$ But, Burton reported, Evatt wanted him to report to him personally: 'in other words, he refuses to allow me to be an officer of the Department. ${ }^{6}$ Burton was soon colluding with Evatt's tendency to work outside official channels of communication and keep his permanent officials in the dark, and this was to cause friction.

Hasluck shared to the full Evatt's mistrust of American ambitions for postwar hegemony in the South Pacific, especially after the Cairo Conference of November 1943 when the United States, Britain and Nationalist China took decisions about the future of Japan's colonies without consulting Australia and New Zealand. ${ }^{7}$ To protect their interests, Evatt convened a conference between the two governments at Canberra on 21 January 1944. Hasluck was put in charge of the arrangements and appointed secretary to the conference.

The result was an unprecedented formal treaty in which Australia and New Zealand agreed to consult regularly about regional foreign policy, defence, commerce and the fostering of full employment. They claimed a place at any peace-making conference table and a voice in deciding the future sovereignty of any of the Pacific islands. ${ }^{8}$ Although Hasluck later commented that the calling of the conference reflected Evatt's 'almost psychological antipathy to any power that was greater than Australia', ${ }^{9}$ he described his own standpoint as 'offensively Australian' ${ }^{10}$ and fully shared Evatt's view that Australia should shape its own foreign policy in accordance with its own regional interests. The United States should not be encouraged to seek hegemony in the South-West

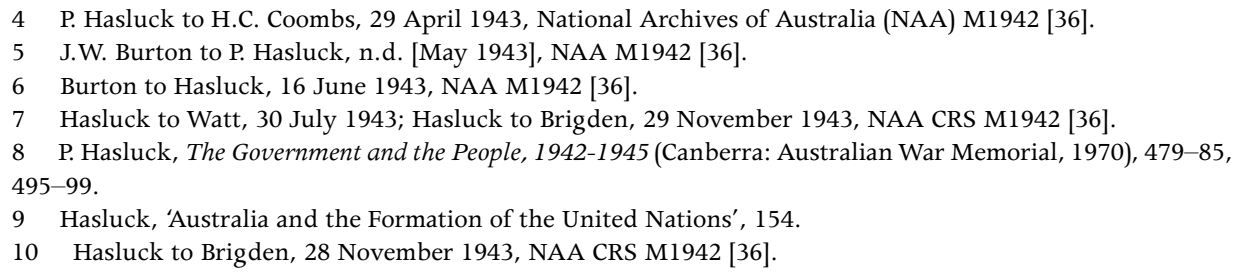


Pacific but need not be provoked unnecessarily. Here he differed from Evatt in tone rather than substance. Hasluck was already aware that, in an international community shaped first and foremost by power relationships, Australia must use judgment in achieving effect while working within its limitations.



Paul Hasluck, 1954

Source: National Archives of Australia, A1200, L16892 
Hasluck's great contribution to the Canberra conference lay in his skill as a draftsman, finding forms of words that would reconcile differing points of view. In such exercises he found some of the same intellectual pleasure as he did in writing poetry, especially when he was teamed with an expert jurist in Kenneth Bailey. He was formidably hardworking, at least once working throughout the entire night. His colleague, Patrick Shaw, wrote: 'Everyone attributes a large part of the speedy agreement to the preparatory work, and that means you and your section.'11 In old age John Burton commented that Hasluck was a very good bureaucrat with no sign of an underlying philosophy. ${ }^{12}$ As Peter Edwards has suggested, Hasluck and Burton supplied different needs for Evatt, 'the one relatively orthodox, the other more idealistic and adventurous' ${ }^{13}$

The rivalry between Hasluck and Burton grew during 1944, as it was never made clear whether the Economic Relations section of External Affairs headed by Burton was separate from Hasluck's Post-War Hostilities Division or subordinate to it. Ric Throssell, then a diplomatic cadet, recalled:

And you had this ludicrous situation going on, with Hasluck writing on cables, 'Dr Burton, please advise', and Burton would screw 'em up and throw 'em into the waste paper basket and then go down and get another clean copy for himself ... There was a huge rivalry between them. ${ }^{14}$

In September 1944, fed up with the wrangling, Hasluck submitted his resignation, but Evatt persuaded him to withdraw it. Hasluck was still a temporary appointee to the Department of External Affairs, expecting to serve until 1947 when he would start work on writing the home front section of the official history of Australia in the Second World War. ${ }^{15}$ For the present he was in Evatt's good books, and Evatt placed increasing reliance on him.

When the Great Powers met at Dumbarton Oaks in August-September 1944 to plan the structure of the United Nations, the British delegation took care to consult Australia. Evatt concerned himself mostly with broad principles and left the detailed submissions to be drafted by Hasluck and Bailey. ${ }^{16}$ At the Wellington conference between Australia and New Zealand in November 1944, Evatt was ill and it was left to the departmental officers, Hasluck, Burton

\footnotetext{
11 P. Shaw to P. Hasluck, 26 January 1944, NAA CRS M1942 [36].

12 J.W. Burton interview with author, 26 May 2004.

13 P.G. Edwards, Prime Ministers and Diplomats: The Making of Australian Foreign Policy 1901-1949 (Melbourne: Oxford University Press, 1983), 147.

14 Don Baker oral history interview, 30 January - 3 March 1992 (National Library of Australia).

15 For the attempt at resignation Hasluck to Dunk, 25 March 1947, NAA CRS M1943 [16]; for his appointment to the Official War History, Long to Hasluck, 27 August 1943; Hancock to Long, 3 September 1943; Long to Hasluck, 13 October 1944; official contract, Hasluck MSS, Claremont.

16 Hasluck, Diplomatic Witness, 145.
} 
and W.D. Forsyth, to exercise their own discretion; Hasluck thought that this made for greater precision in the conference's statements about international organisation, trusteeship and colonial policy. ${ }^{17}$

For the San Francisco conference setting up the United Nations, Curtin decided to send the deputy prime minister, Francis Forde, together with Evatt, but never clearly spelt out which of the two should lead the delegation. With both men out of the way the ailing Curtin could give the treasurer, Ben Chifley, a clear run to establish his credentials as acting prime minister and likely successor. Evatt's response was to mobilise the strongest possible support team, including Hasluck, Burton, Bailey, Watt and Forsyth.

Before the San Francisco conference the Australian delegation went to London between 4 and 13 April. It was meant to be 'a rather mild family talk, at which the United Kingdom ... would give information and explanations to the Dominions and answer their questions in order to assist their preparations ${ }^{\prime}{ }^{18}$ Evatt changed that. Comprehensively briefed by Hasluck and Bailey and working with furious concentration, he soon made it clear that he controlled Australia's policy and that Australia would not always comply with Britain. The patriot in Hasluck was not unhappy with this state of affairs, though he disagreed with Evatt's thinking on colonial issues. To his wife Hasluck wrote: Australia took quite a prominent part ... and in this case I think it can be fairly stated that Australia was Evatt, Bailey and myself.' ${ }^{19}$

The San Francisco conference began on 25 April and was scheduled to close at the end of May; in the event it was prolonged until 15 June. Very quickly Evatt and his officials, augmented by Bailey, established themselves as the makers of Australian policy. The work of the conference was divided between four commissions. Evatt ensured that one of his officers was appointed secretary and executive officer of each of the Australian delegations to these commissions. Hasluck's duties included the daily coordination of committee meetings and the briefing of Australia's representatives. In the eyes of an observer who saw much of the action at this time:

Hasluck, I think, more than anybody, was responsible for framing the policies that Evatt followed in the post-war world. From the time in 1943 when Evatt fastened his attention to what the post-war world would be like - what Australia's role should be in it - Hasluck was the principal guide that fed the ideas into him. There were others such as Bill Forsyth, Ken Bailey, etc. etc. but Hasluck was the main one, the main architect of policies. And he worked like a Trojan for Evatt ... ${ }^{20}$

17 Ibid., 148; Edwards, Prime Ministers and Diplomats, 164.

18 Ibid., 193 and ch. 17 generally.

19 P. Hasluck to A. Hasluck, 17 April 1945, Hasluck MSS, Claremont.

20 Alan Renouf, oral history interview, 23 November 1993, National Library of Australia (NLA) TRC 2981/6. 
Early in the San Francisco discussions Hasluck succumbed to a mood of disenchantment. He told his wife: 'I become more and more cynical watching this crowd at work and less certain that truth is ever to be found from the lips of man.' ${ }^{21}$ From this abyss of pessimism he soon raised himself by a growing realisation that all the desperately hard work by Evatt and his team was producing positive results. In a later letter describing the delegates as 'a collection of monomaniacs all trying to put something across their neighbours', he also wrote, 'the Australian delegation is going pretty well and is getting a great number of things it wants, so although the spiritual climate is not very exhilarating there is a certain amount of good humour around the place' ${ }^{22}$ Under the intensive pressure of working for a common goal, the Australian delegation suspended most of their office jealousies. Hasluck found himself praising Evatt's tremendous capacity for work, forming close alliances with Bailey and Watt, and even writing about Burton in complimentary terms. ${ }^{23}$

When the time came to set up a 14-nation committee to integrate the findings of the working parties into the text of the United Nations charter Hasluck and Bailey were nominated to membership. Evatt told them: 'Go ahead and use your own judgment.' ${ }^{24}$ The task was completed after days of intense pressure. Hasluck's mood was one of relief and elation. Evatt, he wrote, 'has certainly made his mark in this conference and established Australia as, next to the Great Powers, one of the most important and influential delegations at the conference'. ${ }^{25}$ 'The effort has been worth it ... [Evatt] has made me proud to be an Australian and particularly to be one of the same team. He really has fought magnificently and with great judgment in very difficult circumstances. ${ }^{26}$

These comments made to his wife in the immediate aftermath of the San Francisco conference contrast with Hasluck's verdict in later years:

[Evatt] was working for a success at San Francisco rather than addressing himself to the continuing tasks of good international relations. He was eager to play a leading role in making the Charter and of being the champion of small powers. His ambition was clearer than his policy. ${ }^{27}$

For the present, the halcyon mood continued. On the voyage home across the Pacific the Evatts, Hasluck, Burton and Sam Atyeo and his wife settled down to a peaceful existence of relaxation and reading, the greatest antagonisms arising from that most competitive of shipboard games, deck quoits. Never previously close,

21 P. Hasluck to A. Hasluck, 9 May 1945, Hasluck MSS, Claremont.

22 P. Hasluck to A. Hasluck, 26 May 1945.

23 P. Hasluck to A. Hasluck, 5 May 1945 and 1 June 1945.

24 P. Hasluck to A. Hasluck, 1 June 1945 and 18 June 1945.

25 P. Hasluck to A. Hasluck, 13 June 1945.

26 P. Hasluck to A. Hasluck, 25 June 1945.

27 Hasluck, 'Australia and the Formation of the United Nations', 177. 
Hasluck and Sam Atyeo discovered a common enthusiasm for jazz. Even the news that Curtin had died and that Chifley had been elected leader by a substantial margin over Forde did not long disturb the tranquillity of the voyage. ${ }^{28}$

During the next 18 months, relations soured between Hasluck and Evatt. It is not necessary to seek an explanation by casting Burton as an Iago figure fanning suspicion in Evatt's mind, although undeniably Burton's propensity for gossip was unhelpful. ${ }^{29}$ But as Hasluck gained in experience and confidence his views were diverging from Evatt's. His idealism was giving way to a cold-eyed pragmatism. He questioned Evatt's attempts to limit the authority of the Great Powers, doubted the practicality of a commitment to full employment, and thought Australia was over-extending its interventions into other nations' affairs. ${ }^{30}$

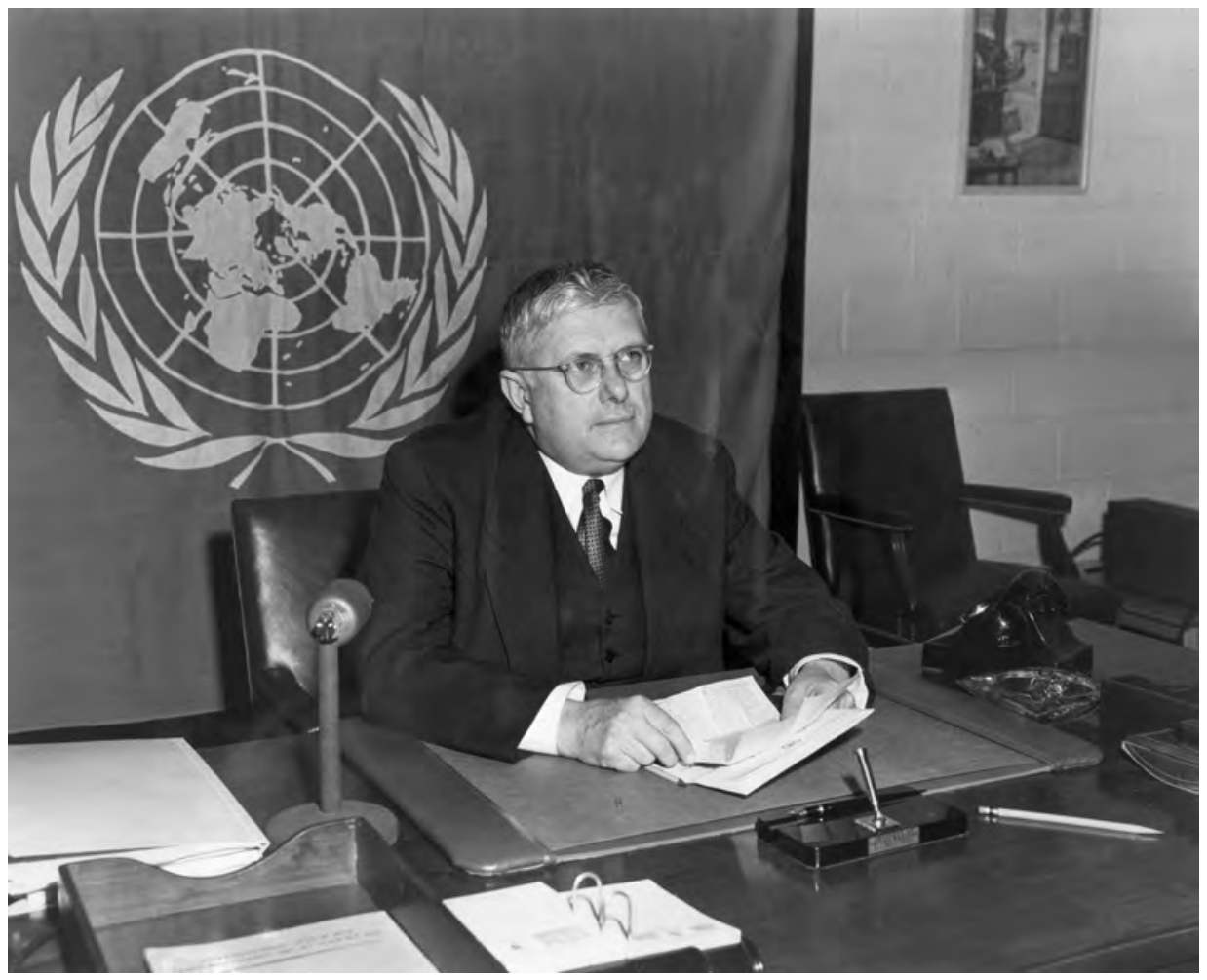

Dr H.V. Evatt at the United Nations, 1949

Source: National Archives of Australia, A6180, 23/8/79/118

28 Hasluck, Diplomatic Witness, ch. 21.

29 I do not have space in this paper to give examples, but evidence may be found not only in Hasluck's writings but also in L.F. Crisp's San Francisco diary (NLA) and in Alan Renouf's correspondence (Renouf to Hasluck, 'Paris/Sunday' [August 1946], NAA CRS M1943 [12]).

30 Hasluck, Workshop of Security, 178. 
These divergences did not surface while Hasluck was in London between August 1945 and February 1946 for the preliminary discussions setting up the United Nations. Hasluck shepherded Evatt's interests devotedly, pressing his claims for the first presidency of the General Assembly. ${ }^{31}$ In the event, Paul-Henri Spaak of Belgium was chosen. Hasluck thought that British disapproval might have prejudiced Australia's chances. ${ }^{32}$ The Australians were no more successful in the debate about the future site of the United Nations headquarters. Evatt was eager for San Francisco, a venue that he thought would ensure attention to the Pacific region. The Great Powers, the Europeans and the Latin Americans all preferred a site on the Atlantic coast of the United States. Hasluck found himself in a minority of one. ${ }^{33}$ The choice soon went to New York. However, Australia gained one of the elected seats on the Security Council after Canada gracefully withdrew from contesting it. ${ }^{34}$

Hasluck's performance at London sufficiently commended itself to Evatt for his appointment as counsellor-in-charge of the Australian mission to the United Nations and acting representative on the Atomic Energy Commission. The leadership of the delegation went to Norman Makin, newly appointed ambassador to Washington, who found himself thrust into the chairmanship of the Security Council as the result of a decision that each delegation should hold the office for a month in turn in alphabetical order. Makin was a modest, decent old warhorse of the federal Labor Party who had been speaker of the House of Representatives when the Scullin Government held office and minister for the Navy under Curtin but had no more experience of foreign affairs than Forde. 'Makin thanked the Council effusively for being first chairman. While Hasluck's face preserved an oriental calm, Watt's constantly moving with nervous coughs, and Bailey's showed absolute disbelief, there was raucous comment and guffaws of laughter from Sam Atyeo.' ${ }^{\prime 3}$ But Makin showed himself prepared to take advice and express appreciation, and the work of the Security Council proceeded smoothly. Colonel Hodgson, formerly secretary of External Affairs and now ambassador to France, was sent to New York to take over from Makin, but he returned to Paris because of his wife's serious illness, leaving Hasluck to head the delegation.

In May 1946, Australia was represented on two committees dealing with major issues of contention. One concerned the fitness of Spain, then under the Franco dictatorship, for admission to the United Nations. The other was examining an Iranian complaint about a perceived Soviet threat in the border region of

31 Hasluck to Evatt, 12 December 1945, NAA CRS M1942 [22]; also Hodgson to Evatt, 14 December 1945, NAA CRS M1774 [23].

32 Hasluck to Evatt, 12 December 1945, NAA CRS M1942 [22].

33 Ibid.; see also Evatt to Hodgson and Hasluck, 20 December 1945, NAA CRS M1774 [23].

34 Hasluck to Dunk, 19 January 1946, NAA CRS M1943 [1].

35 A. Renouf, The Champagne Trail: Experiences of a Diplomat (Melbourne: Sun Books, 1980), 19. 
Azerbaijan. The Russians walked out of the Security Council in protest against the discussion of this topic. Evatt gave no instructions to the Australian delegation, and Hasluck used the debate to attack the Soviet Union for opting out of the processes of international peacemaking. His speech made a strong impact in the press; the evening papers in New York carried photographs of him with glowing references to him as a young diplomat. ${ }^{36}$

Evatt was not pleased. Renouf later reported: 'He maintains that this was a breach of instructions and Molotov was very incensed with it. I think the real reason, however, is the publicity you received for your work.' ${ }^{37}$ Evatt asked Renouf to send him a weekly report on 'what Hasluck was up to', adding, 'I think he's building himself up, not me'. When Renouf refused, Evatt said: 'I'll fix you.' But there was no showdown when Evatt arrived in New York later in May. He concentrated on the Atomic Energy Commission, keeping Hasluck extremely hard at work as Evatt's draftsman, sometimes in all-night sessions. Hasluck was unimpressed with Evatt's performance as temporary chairman of the Atomic Energy Commission. He seemed 'hell bent' on securing a treaty creating an international atomic energy authority and a system of control without building up understanding between the United States and the Soviet Union. Evatt left at the end of June with the central issue unresolved, leaving Hasluck, assisted by Ralph Harry and two distinguished scientists, George Briggs and Mark Oliphant, to spend the rest of the year working on many technical problems. ${ }^{38}$

For the rest of 1946 Hasluck worked ceaselessly, took part in a busy social round, and gained more publicity, although he swore that he tried to deflect the media to Evatt. ${ }^{39}$ In December it was once again Australia's turn to chair the Security Council. Evatt sent word that Makin, and not Hasluck, would fill the role. Hasluck snapped. In his eyes Makin's nomination undermined his standing and suggested that he lacked the government's confidence: 'If it signifies my replacement I would appreciate plain advice to that effect.' ${ }^{40}$ Mainly because of Makin's tact the tensions subsided for a while. Hasluck refused an offer of appointment as head of the European section of the United Nations, with headquarters in London and a salary of US\$10,000 a year. Trouble erupted again in February 1947 when word arrived that Burton would become the secretary of the Department of External Affairs.

Hasluck sent in his resignation, stating that he was not influenced by issues of salary or status, nor because of lack of promotion, nor because of the strain on his health, but because 'by Burton's appointment Cabinet set its approval

\footnotetext{
36 A. Hasluck to E. Darker, 22 May 1946, Hasluck MSS, Claremont.

37 Renouf to Hasluck, 'Paris/Saturday' [August 1946], NAA CRS M1943 [12].

38 Ibid., 279.

39 Ibid., 282.

40 Hasluck to Evatt, 14 December 1945, NAA CRS M1943 [16].
} 
on a whole system of petty intrigue, talebearing, favouritism and personal attachment to the Minister which as an Australian citizen I consider contrary to public service principles. ${ }^{41}$ Evatt told Hasluck that his judgment was affected by personal feelings, and there was perhaps just enough truth in the comment to make it rankle. A journalist who observed Evatt closely remarked that he had a rough, sometimes precise insight into those who worked for him. He seemed to know the exact tactic or word likely to reduce them to size. ${ }^{42}$ But in his own family circle Evatt uttered no criticism of Hasluck harsher than that he was 'pernickety'. ${ }^{43}$

Hasluck's wife Alexandra, a dismayed spectator of her husband's treatment, thought of an elegant rejoinder. She told her mother that Paul should go into parliament and become minister for External Affairs. 'He is fed up with the diplomatic life ... but I think he would like the running of foreign policy.' ${ }^{44}$ From his previous stance as a middle-of-the-road agnostic in politics, Hasluck was now moving towards support of the Liberal Party under Robert Menzies. Eventually the scenario unfolded as Alexandra Hasluck had predicted, though it is debatable whether it benefited either her own personal happiness or her husband's sense of achievement. As the old Chinese proverb has it: 'Be careful what you wish for, as your wish may be granted.'

Hasluck was returned to the House of Representatives for the safe seat of Curtin in December 1949, taking his seat on the government back benches opposite Evatt in his new role as deputy leader of the Opposition. Parliamentary legend has it that whenever Hasluck was scheduled to speak Eddie Ward would tell Evatt that Hasluck was about to 'spill the beans' about his past experiences in External Affairs, and Evatt would rush into the House in a state of perturbation. But Clyde Cameron, that devoted historian of the federal Labor Party, told a kindlier story. Years later in the 1960s, when Evatt's powerful intellect had been brought low by illness, only two members of parliament came to visit him in his twilight world. One was Justin O'Byrne, a notably good-natured Tasmanian senator. The other, by now a busy Cabinet minister, was Paul Hasluck. Patiently he sat with Evatt yarning about their experiences in San Francisco and trying to rouse him with talk of men and events whom they both knew. ${ }^{45}$ It was a graceful conclusion to a sometimes fraught relationship.

\footnotetext{
41 Hasluck to Dunk, 25 March 1947, NAA M1943 [16].

42 R. Donnington, 'Evatt at Large', Observer, 15 September 1958.

43 Interview with Mrs Rosemary Carrodus, 29 November 2009.

44 A. Hasluck to E. Darker, 17 February 1947 and 23 April 1947, Hasluck MSS, Claremont. John Burton (interview, 26 May 2004) thought that when Hasluck resigned he was aware that Menzies was interested in him as a possible recruit to parliament, but I have found no evidence for this.

45 Interview with Clyde Cameron, 12 November 2002.
} 
This text is taken from The Seven Dwarfs and the Age of the Mandarins: Australian Government Administration in the Post-War Reconstruction Era, edited by Samuel Furphy, published 2015 by ANU Press, The Australian National University, Canberra, Australia. 